\title{
PENGUATAN PROGRAM PENDIDIKAN KARAKTER (PPK) MELALUI KEGIATAN EKSTRAKULIKULER SENI TARI DI SD
}

\author{
Dita Ihsaniah Putri \\ PGSD Fakultas IImu Pendidikan Universitas PGRI Semarang \\ ditaip17@gmail.com
}

\begin{abstract}
Character Education Strengthening (KDP) is an educational movement in schools to strengthen students' character through harmonization of heart (ethics), taste (aesthetics), thinking (literacy), and sports (kinesthetic) with the support of public involvement and cooperation between schools, family and community. The five main values of KDP priority characters are Religious, Nationalist, Mutual Cooperation, Integrity, Mandiri. But we now know that character education at this time seems to be still low in morale of students. For this reason the aim of this study is to find out the Implementation of Character Education through Extracurricular Activities in the dance arts of Semarang and surrounding elementary schools, and to know the supporting and inhibiting factors of the character education of students. This research is a qualitative description research. The technique of retrieving data and observations is obtained through using questionnaires or questionnaires, interviews, and documentation.
\end{abstract}

Keywords: Influence, Character Education, Dance.

\section{ABSTRAK}

Penguatan Pendidikan Karakter (PPK) adalah gerakan pendidikan di sekolah untuk memperkuat karakter siswa melalui harmonisasi olah hati (etik), olah rasa (estetis), olah pikir (literasi), dan olah raga (kinestetik) dengan dukungan pelibatan publik dan kerja sama antara sekolah, keluarga, dan masyarakat. Lima nilai utama karakter prioritas PPK adalah Religius, Nasionalis, Gotong Royong, Integritas, Mandiri. Namun kita ketahui sekarang bahwa pendidikan karakter saat ini tampak masih rendahnya moral peserta didik. Untuk itu penelitian ini bertujuan untuk mengetahui Impelementasi Pendidikan Karakter Melalui Kegiatan Ekstrakulikuler Seni tari di SD Semarang dan sekitarnya, serta mengetahui faktor pendukung dan penghambat pendidikan karakter peserta didik. Penelitian ini merupakan penelitian deskripsi kualitatif. Teknik pengambilan data dan observasi diperoleh melalui menggunakan angket atau kueisioner, wawancara, dan dokumentasi.

Kata kunci: Pengaruh, Pendidikan Karakter, Seni Tari. 


\section{A. Pendahuluan}

Karakter merupakan gambaran diri seseorang yang sesungguhnya karena setiap orang memiliki karakter dan itu bisa dilihat dari diri seseorang yang sebenarnya apakah baik atau buruk. Karakter dilakukan seseorang ketika tidak ada yang memperhatikan oleh sebab itu karakter bisa dimaknai sebagai cara berfikir dan berperilaku yang khas di setiap individu supaya baik dalam lingkup keluarga, masyarakat, bangsa dan negara. Individu yang berkarakter baik adalah individu yang dapat membuat keputusan dan siap mempertanggungjawabkan setiap akibat yang dilakukan.

Karakter yang dimiliki siswa sekarang mulai berkurang karena di dalam dirinya belum ditanamkan karakter misal kurang menghormati orang tua, belum bisa menjaga kebudayaan yang dimiliki negara oleh sebab itu karakter harus bisa ditanamkan pada diri siswa mulai sejak kecil kalau tidak siswa akan mempunyai karakter yang kurang baik.

Kegiatan ekstrakulikuler yang diadakan oleh pihak sekolah supaya bisa membuat siswa tertarik untuk mengikuti kegiatan tersebut. Misal kegiatan ekstrakulikuler yang dimiliki oleh beberapa SD di Semarang dan sekitarnya khususnya ekstrakulikuler seni tari merupakan ekstrakulikuler yang banyak diikuti oleh siswa dan sudah banyak mendapatkan prestasi dalam tingkat kejuaran.

Melalui kegiatan ekstrakulikuler seni tari diharapkan dapat mengembangkan kemampuan dan rasa tanggung jawab sosial, potensi serta prestasi yang dimiliki siswa. Hal itu diharapkan supaya penanaman nilai karakter melalui kegiatan ekstrakulikuler seni tari secara mendalam sehingga benar - benar akan membentuk kepribadian peserta didik sesuai nilai karakter yang ditanamkan.

Ekstrakulikuler seni tari merupakan wadah untuk mengembangkan nilai karakter serta penanaman nilai karakter yang religius, jujur, toleransi, disiplin, kerja keras, semangat kebangsaan, demokratis, menghargai prestasi, bersahabat, cinta damai, peduli sosial, cinta tanah air, bertanggung jawa.

Ekstrakulikuler seni tari juga bagus untuk perkembangan peserta didik karena ekstrakulikuler biasanya 
Pendas : Jurnal Ilmiah Pendidikan Dasar, ISSN Cetak : 2477-2143 ISSN Online : 2548-6950 Volume IV Nomor 01, Bulan Tahun 2019

diikutkan dalam perlombaan di tingkat kecamatan maupun kota.

Ironisnya kondisi di lapangan menunjukkan fakta belum maksimalnya ketercapaian tujuan pendidikan karakter. Untuk mengetahui bagaimana nilai karakter siswa melalui ekstrakulikuler seni tari yang ada di SD Semarang maka peneliti harus melakukan observasi terlebih dahulu sebelum kegiatan ekstrakulikuler dilaksanakan atau sebelum memulai latihan.

Dan untuk lebih dalam bisa mewawancarai pelatih atau guru tari yang mengajarkan seni tari yang mengajarkan seni tari serta salah satu peserta didik yang mengikuti ekstrakulikuler seni tari tersebut bisa melihat langsung karakter yang dimiliki atau yang ada pada peserta itu seperti apa misal rasa tanggung jawab, jujur, disiplin, toleransi.

Berdasarkan uraian yang telah dijabarkan, maka peneliti bertujuan untuk melakukan penelitian dengan judul Penguatan program Pendidikan Karakter Melalui Kegiatan Ekstrakulikuler Seni Tari Di SD.

Manfaat penelitian ini diharapkan dapat meningkatkan karakter peserta didik menjadi lebih baik dan berpendidikan sebagaimana mestinya

\section{B. Landasan Teori}

1. Pengertian Pendidikan Karakter

Pendidikan yang bertujuan melahirkan insan cerdas dan berkarakter kuat pernah dikatakan Martin Luther King, yaitu "Kecerdasan yang berkarakter adalah tujuan akhir pendidikan yang sebenarnya" (Anas S. Dan Irwanto A. 2013:42). Dengan demikian pendidikan karakter seharusnya dapat diterapkan disegala kegiatan pendidikan baik formal maupun non formal. Karena pendidikan yang berkarakter akan memberikan makna atau sesuatu yang lebih baik kepada seseorang. Pendidikan karakter dalam Anas S. Dan Irwanto A. (2013:42) dapat dimaknai sebagai pendidikan nilai, pendidikan budi pekerti, pendidikan moral, pendidikan watak yang bertujuan mengembangkan siswa untuk memberikan keputusan baikburuk, memelihara kebaikan, mewujudkan dan menebar kebaikan dalam kehidupan sehari - hari dengan sepenuh hati.

Berdasarkan teori di atas dapat diketahui bahwa pendidikan karakter merupakan sistem untuk menanam 
Pendas : Jurnal IImiah Pendidikan Dasar, ISSN Cetak : 2477-2143 ISSN Online : 2548-6950

Volume IV Nomor 01, Bulan Tahun 2019

nilai - nilai karakter yang harus

dilaksanakan dan melibatkan semua pihak baik rumah tangga dan keluarga, sekolah dan lingkungan sekolah, masyarakat luas. Tidak hanya perserta didik yang melaksanakan pendidikan karakter tetapi guru, kepala sekolah, penjaga sekolah, staf tata usaha, dan warga sekolah yang lain ikut berperan untuk melaksanakan pendidikan karakter. Usaha dasar dan terencana dari warga sekolah untuk melaksanakan nilai karakter mampu mengembangkan karakter dengan maksimal dengan itu dapat mempengaruhi contoh perilaku yang tampak dari lingkungan sekitar tempat perserta didik biasa melakukan interaksi di sekolah.

2. Pembentukan Karakter

Dalam rangka untuk memperkuat pelaksanaan pendidikan karakter telah teridentifikasi 18 nilai yang bersumber dari agama, pancasila, budaya, dan tujuan pendidikan nasional, yaitu:

Religius, (2) Jujur, (3) Toleransi, (4) Displin, (5)Kerja Keras, (6) Kreatif, (7) Mandiri, (8) Demokrasi, (9) Rasa Ingin Tahu, (10) Semangat Kebangsaan, (11) Cinta Tanah Air, (12) Menghargai Prestasi,
Bersahabat/ Komunikatif, (14) Cinta

Damai, (15) Gemar Membaca, (16) Peduli Lingkungan, (17) Peduli Sosial, (18) Tanggung Jawab. Meskipun telah terdapat 18 nilai pembentukan karakter bangsa, namun satuan pendidikan dapat menentukan prioritas pengembangannya dengan cara melanjutkan nilai prakondisi yang diperkuat dengan beberapa nilai yang diprioritaskan dari 18 nilai diatas (Daryanto 2013 : 47).

\section{Pendidikan Dasar}

Karakteristik anak usia sekolah dasar tidak hanya itu. karakteristik anak sekolah dasar yaitu: (1) senang bermain peserta didik sekolah dasar terutama yang masih di kelas rendah pada umumnya masih suka bermain sehingga guru mampu mengembangkan pembelajaran yang bermuatan permainan, contohnya anak - anak biasanya menari - nari dengan gayanya (2) senang bergerak peserta didik sangat aktif bergerak dan hanya bisa duduk dengan tenang sekitar 10 menit saja. Contohnya dalam latihan kegiatan ekstrakulikuler seni tari anak lebih suka menari walaupun itu saat latihan istirahat, (3) senang bekerja dalam kelompok dengan bergaul dalam kelompoknya 
Pendas : Jurnal Ilmiah Pendidikan Dasar, ISSN Cetak : 2477-2143 ISSN Online : 2548-6950

Volume IV Nomor 01, Bulan Tahun 2019

peserta didik belajar bersosialisasi, belajar bagaimana bekerja dalam kelompok, belajar setia kawan dan belajar mematuhi aturan-aturan dalam kelompok. (4) senang merasakan atau melakukan sesuatu secara langsung, peserta didik berusaha menghubungkan konsepkonsep yang sebelumnya telah dikuasai dengan konsep-konsep yang baru dipelajari. Suatu konsep juga akan cepat dikuasai peserta didik apabila peserta didik dilibatkan langsung melalui praktik dari apa yang diajarkan guru.

\section{Penanaman Karakter}

Penanaman secara etimologis berasal dari kata tanam yang berarti meletakkan atau menaruh bibit, yang semakin jelas jika mendapatkan awalan pe - dan akhiran -an menjadi "Penanaman" yang berarti proses atau cara, perbuatan menanam, menanami atau menanamkan. Jadi penanaman dapat dikatan sebagai proses pembentukan terhadap sesuatu yang dilaksanakan secara terus menerus. Nilai merupakan sesuatu yang berharga bagi seseorang untuk dijadikan sebagai tolok ukur dalam menjalankan kehidupan.
Karakter merupakan ciri khas seseorang atau sekelompok orang yang mengandung nilai, kemampuan, kapasitas moral, dan ketegaran dalam menghadapi kesulitan dan tantangan. (Anas S. Dan Irwanto A, 2013:42).

Berdasarkan beberapa teori yang disampaikan dapat disimpulkan bahwa karakter merupakan suatu sifat - sifat yang dimiliki oleh seseorang yang terwujud dalam pikiran, sikap, perasaan, perkataan yang melekat dan dapat dijadikan sebagai identitas diri.

5. Ekstrakulikuler

Ekstrakulikuler adalah kegiatan pendidikan di luar mata pelajaran untuk membantu pengembangan perserta didik sesuai dengan kebutuhan, potensi, bakat, dan minat mereka melalui kegiatan yang secara khusus di selenggarakan oleh pendidik dan atau tenaga kependidikan yang berkemampuan dan berkewenang di sekolah. (Maryati, 2007:53).

6. Seni Tari

a. Pengertian Seni

Seni merupakan salah satu upaya manusia untuk menyatu dengan lingkungan. Seni juga dikatakan sebagai suatu usaha 
Pendas : Jurnal IImiah Pendidikan Dasar, ISSN Cetak : 2477-2143 ISSN Online : 2548-6950

Volume IV Nomor 01, Bulan Tahun 2019

manusia untuk memenuhi kebutuhan

aktualitas diri. Seni juga bisa diartikan sebagai alat komunikasi yang halus karena simbolis yang terkadung dalam karya seni yang bersangkutan sehingga dalam seni dituntut lebih banyak persyaratan untuk dapat mengungkapkan misi yang akan disampaikan (Yenni Patriani Yakub, 2010:02).

b. Pengertian Tari

Annayanti Budiningsih (2010:01) tari adalah gerak tubuh secara berirama yang dilakukan di tempat dan waktu tertentu untuk keperluan pergaulan, mengungkapkan perasaan, maksud, dan pikiran. Bunyi - bunyi yang disebut musik pengiring tari mengatur gerakan tari berbeda dari gerakan sehari - hari seperti berlari., berjalan, atau bersenam.

Dari berbagai teori dapat diartikan seni tari adalah gerak tubuh manusia dipakai untuk mengungkapkan ide - ide, perasaan, dan pengalaman sang seniman kepada orang lain yang diiringi dengan musik atau irama - irama tertentu.

\section{Metode Penelitian}

Jenis penelitian yang digunakan dalam penelitian ini adalah deskriptif kualitatif. Prosedur pengumpulan datanya menggunakan observasi, wawancara, dan dokumentasi. Sumber data penelitian menggunakan informan dan dokumentasi. Teknik analisis data menggunakan tiga komponen utama, yaitu reduksi data, penyajian data, dan penarikan kesimpulan.

\section{Hasil dan Pembahasan}

Dari penelitian yang sebelumnya dilakukan (oleh Inna Annisa, 2015) tentang penanaman nilai karakter siswa melalui kegiatan ekstrakulikuler tembang jawa di SDN Muktiharjo kidul 01 Semarang. Masalah yang dikaji dalam penelitian ini adalah hasil karakter siswa dalam ekstrakulikuler tembang jawa? Dan bagaimana pelaksanaan penanaman nilai karakter terhadap siswa melalui ekstrakulikuler tembang jawa? Penelitian ini bertujuan untuk mengetahui karakter-karakter dalam kegiatan ekstrakulikuler tembang jawa serta mengetahui bagaimana pelaksanaan nilai karakter terhadap siswa melalui ekstrakulikuler tembang jawa dan tujuan terakhir 
Pendas : Jurnal IImiah Pendidikan Dasar, ISSN Cetak : 2477-2143 ISSN Online : 2548-6950

Volume IV Nomor 01, Bulan Tahun 2019

untuk mengetahui bagaimana hasil karakter siswa dalam mengikuti kegiatan ekstrakulikuler tembang jawa.

Berdasarkan hasil penelitian tersebut dapat disimpulkan bentuk penanaman pendidikan karakter pada SDN Muktiharjo Kidul 01 semarang dilakukan dengan kegiatan ekstrakulikuler tembang jawa dan dalam ekstrakulikuler tembang jawa dilakukan melalui pembiasaan kegiatan dalam menghayati makna lagu - lagu jawa dan ketekunan juga terdapat 10 nilai karakter yang ditanamkan dalam kegiatan ekstrakulikuler tembang jawa yaitu: religius, toleransi, mandiri, kerja keras, displin, cinta tanah air, cinta damai, bersahabat/komunikatif, peduli lingkungan dan tanggung jawab. Berdasarkan kajian hasil penelitian yang relevan yang dilakukan oleh Inna Annisa, 2015 itu penelitiannya dilaksanakan di SD Negeri Muktiharjo Kidul 01 Semarang yaitu salah satu SD di kecamatan Pedurungan.

Untuk kajian hasil penelitian yang relevan ini mempunyai fungsi yaitu menambahkan karena dalam penelitian sebelumnya itu mengenai ekstrakulikuler tembang jawa, ekstrakulikuler tembang jawa merupakan salah satu kesenian serta memiliki nilai karakter religius, toleransi, mandiri, kerja keras, displin, cinta tanah air, cinta damai, bersahabat/komunikatif, peduli lingkungan dan tanggung jawab.

Hal tersebut di sesuaikan dengan penelitian yang dilakukan mengenai ekstrakulikuler seni tari dalam ekstrakulikuler seni tari ini menggunakan nilai karakter displin, jujur, religius, toleransi, kerja keras, mandiri, bertanggung jawab, cinta damai, peduli lingkungan, bersahabat/komunikatif. Bisa dilihat dari perserta didik yang mengikuti kegiatan ekstrakulikuler tembang jawa karena sudah tertanam nilai karakternya khususnya perserta didik yang mengikuti kegiatan itu.

Penelitian selanjutnya (oleh Kartika Fajar Pratiwi, 2015) tentang penanaman pendidikan karakter melalui pembiasaan dan keteladanan pada siswa SDN Sedangmulyo 03 Kota semarang. dalam penelitian ini masalah yang dikaji adalah penanaman pendidikan karakter SDN Sedangmulyo 03 kota Semarang? Dan bagaimana penanaman pendidikan karakter melalui pembiasaan dan keteladanan SDN 
Pendas : Jurnal Ilmiah Pendidikan Dasar, ISSN Cetak : 2477-2143 ISSN Online : 2548-6950 Volume IV Nomor 01, Bulan Tahun 2019

sedangmulyo 03 kota Semarang? Penelitian ini bertujuan mengetahui penanaman pendidikan karakter SDN Sedangmulyo 01 kota semarang dan tujuan yang terakhir yaitu mengetahui penanaman pendidikan karakter melalui pembiasaan dan keteledanan pada siswa SD Negeri Sendangmulyo 03 kota Semarang.

Berdasarkan hasil penelitian tersebut dapat disimpulkan SDN Sendangmulyo 03 kota Semarang sudah mengupayakan penanaman pendidika karakter serta bentuk penanaman pendidikan karakter di SDN Sedangmulyo 03 kota Semarang melalui kegiatan pembelajaran di kelas (KMB), pembudayaan di lingkungan sekolah, kegiatan ekstrakulikuler dan tujuan yang terakhir yaitu pelaksanaan pendidikan karakter melalui pembiasaan dan keteladanan dilakukan secara bertahap dengan mengacu pada nilai - nilai karakter bangsa. Berdasarkan kajian hasil penelitian relevan yang sebelumnya dilakukan oleh Kartika Fajar Pratiwi, 2015 ini dilakukan di SD Negeri Sendangmulyo 03 Semarang salah satu SD yang berada di kecamatan Tembalang.
Untuk kajian yang relevan pada penelitian yang sebelummnya tentang penanaman pendidikan karakter melalui pembiasaan keteladanan pada siswa. dalam posisi kajian ini bagi peneliti tidak mendukung atau membatah karena penanaman pendidikan karakter melalui pembiasaan keteladanan pada siswa terkadang belum bisa di tanamkan terkadang siswa itu belum terbiasa melakukan penanaman nilai karakter pada dirinya sendiri maka dari itu penelitian ini tidak mendukung atau membantah tidak sesuai dengan penelitian yang dilakukan oleh peneliti dalam penelitian ini melakukan penanaman nilai karakter melalui kegiatan ekstrakulikuler yang di adakan oleh pihak sekolah. Penelitian yang terdahulu yang dilaksanakan di SDN Muktiharjo Kidul 01 Semarang yaitu penanaman nilai karakter melalui ekstrakulikuler rebana yang mempunyai tujuan supaya siswa yang mengikuti kegiatan mempunyai karakter yang diharapkan. Untuk kajian teori ini posisi yaitu pendukung, karena penelitian yang dilakukan oleh peneliti sama yaitu meneliti kegiatan ekstrakulikuler yang mengandung nilai karakter serta ditanamkan. 
Pendas : Jurnal Ilmiah Pendidikan Dasar, ISSN Cetak : 2477-2143 ISSN Online : 2548-6950

Volume IV Nomor 01, Bulan Tahun 2019

Posisi sebagai pendukung karena kegiatan ini di lakukan di luar jam pembelajaran dan pelaksanaannya seminggu sekali. Kegiatannya dilaksanakan di sore hari. Penelitian ini dianggap pendukung karena ekstrakulikuler rebana dan ekstrakulikuler tari merupakan ekstrakulikuler kesenian serta mempunyai tujuan supaya penanaman karakter itu tercapai.

Kajian - kajian itu digunakan supaya bisa melakukan penelitian yang benar dan sesuai. Karena penelitian itu tidak sesuai data yang akan dikumpulkan pasti tidak akan benar - benar konkret, maka harus mencari penelitian yang relevan supaya mengetahui caranya.

\section{E. Kesimpulan}

Berdasarkan uraian yang telah dipaparkan pada bab-bab sebelumnya, maka dapat diambil kesimpulan bahwa anak yang mempunyai karakter dan prestasi yang baik ternyata bisa didapat dari kegiatan di luar jam sekolah yaitu kegiatan ekstrakulikuler karena kegiatan ekstrakulikuler sudah ada nilai karakter yang tertanam.

Walaupun mayoritas kegiatan ekstrakulikuler masih berkurang peminat atau antusianya akan tetapi membuat perserta didik masih mempunyai prestasi dan nilai karakter pada diri masing-masing untuk khususnya kegiatan ekstrakulikuler seni tari peran orang tua sangat lah bermanfaat yaitu selalu mendukung pada saat anak mengikuti kegiatan ekstrakulikuler pada saat anak tampil dalam perlombaan karena semua itu akan mengasah bakat yang dimiliki oleh perserta didik oleh sebab itu.

Saran yang dapat disampaikan adalah untuk membuat siswa supaya mengikuti kegiatan ekstrakulikuler yang ada di sekolahan khususnya kegiatan ekstrakulikuler seni tari maka harus menggunakan cara dengan memberikan pengumuman kepada semua siswa agar mengikuti kegiatan ekstrakulikuler khususnya ekstrakulikuler seni tari. Untuk kegiatan ekstrakulikuler seni tari dengan cara memberikan pengumuman dan memperlihatkan prestasi yang diperoleh selama mengikuti kegiatan serta memperlihatkan nilai karakter yang ditanamkan pada kegiatan ekstrakulikuler seni tari yaitu nilai karakter displin, jujur, religius, toleransi, kerja keras, mandiri, 
Pendas : Jurnal Ilmiah Pendidikan Dasar, ISSN Cetak : 2477-2143 ISSN Online : 2548-6950

Volume IV Nomor 01, Bulan Tahun 2019

bertanggung jawab, cinta damai, peduli lingkungan, bersahabat/komunikatif.

\section{DAFTAR PUSTAKA}

Sugiyono. (2015). Metode Penelitian Kuantitatif Kualitatif R\&D. Bandung : Alfabeta

Agung, Iskandar. 2012. Strategi Pendidikan Pembangunan Berkelanjutan di sekolah. Jakarta: Bee Media Indonesia.

Ahmadi, Rulam. 2014. Metodologi

Penelitian Kualitatif.

Yogyakarta: Ar - Ruzz Media.

Anas, S Dan Irwanto, A. 2013. Pendidikan Karakter Pendidikan Berbasis Agama \& Budaya Bangsa. Bandung: Pustaka Setia.

Annayanti, Budiningsih. 2010.

Uniknya Tarian Jawa. Bogor: Horizon.

Dalmeri. 2014. Pendidikan Untuk Pengembangan Karakter. Jurnal Pendidikan.

Daryanto. 2013. Implementasi

Pendidikan Karakter di sekolah.

Yogyakarta: Gava Media.

Kaelan. 2010. Pendidikan Pancasila.

Yogyakarta: Paradigma.
Maryati. 2007. Tanya Jawab Tentang

Pengembangan Diri Di Sekolah.

Semarang: CV Ghiyas Putra. Noor,

Rohinah. 2012. Mengembangkan Karakter Anak Secara Efektif di Sekolah dan di rumah. Yogyakarta:

Pustaka Insan Mandiri.

Pekerti, Widia,dkk. 2001. Pendidikan Seni Musik - Tari/ Drama. Jakarta: Universitas Terbuka.

Purwatiningsih dan Ninik Hartini. 2004. Pendidikan Seni Tari Drama di TK - SD. Malang: Universita Negeri Malang.

Solihah, Marliya. 2013. Penanaman Karakter Pada Siswa di MAN Wonokromo Bantul . Skripsi. Jogjakarta : Universitas Sunan Kalijaga Yogyakarta.

Sudharto,dkk. 2012. Pengantar IImu Pendidikan. IKIP PGRI Semarang Press: Semarang. 